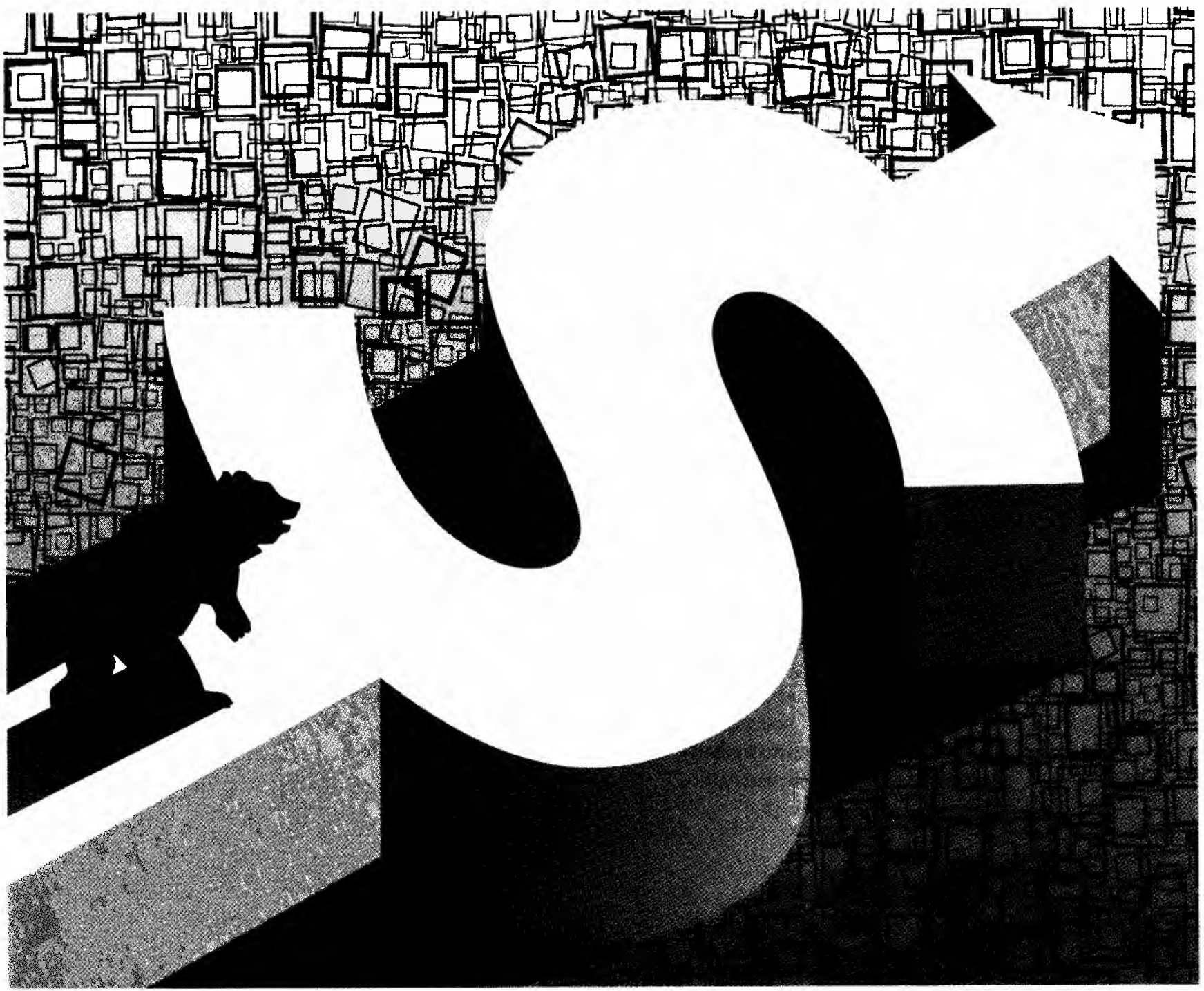

\title{
DESAGREGAÇÃO DO SISTEMA SOVIÉTICO E TRANSFORMAÇÃO DAS FORMAS DE PROPRIEDADE
}

\section{- João Bernardo}

Escritor, autor de vários livros, sendo os mais recentes Crise da Economia Soviética, Dialéctica da Prática e da Ideologia e Economia dos Conflitos Sociais .

* RESUMO: Depois de definir duas formas de propriedades características da classe dos gestores, o autor relaciona a sua evolução com as transformações operadas no aparelho de Estado. Descreve vários processos recentes de privatização na Europa do Leste, concluindo que essas transformações nas formas de propriedade permitem à classe dos gestores manter-se no poder.
* PALAVRAS-CHAVE: Classe dos gestores, formas de propriedade, economias soviéticas, privatização.

* ABSTRACT: The author defines two systems of property distinctive of the managerial class, and relates their development to the transformation of the political apparatus. He describes several recent privatization processes in Eastern Europe, concluding that the changes in the systems of property allow the managerial class to keep in power.

* KEY WORDS: Managerial class, systems of property, Soviet economies, privatization. 
No capitalismo têm até agora existido duas classes sociais dominantes: os gestores, que autores como Bresser Pereira e Prestes Motta denominam tecnoburocracia, e a burguesia. Estas classes distinguem-se, entre outros aspectos, quanto às formas gerais de propriedade. Os burgueses são proprietários privados dos meios de produção; os gestores apropriam-se deles coletivamente, tanto no âmbito de um país, como de uma empresa ou grupo econômico. A diferença não é de pouca importância, sobretudo para as relações entre cada uma dessas classes e a classe trabalhadora. Até há não muito tempo os grandes movimentos de contestação tenderam a reduzir a ordem econômica e social à propriedade privada dos meios de produção, condenando os trabalhadores ao insucesso quando uma modificação das formas de propriedade reforçava, sob a égide dos gestores, o mesmo capitalismo que só havia sido posto em causa na sua vertente burguesa. Estas operações de recuperação das lutas sociais conseguem hoje um novo fôlego, mediante a transformação interna do próprio sistema gestorial de propriedade.

Quanto às formas de propriedade da classe dos gestores, tenho usado um modelo em que, nos países que seguiam o regime soviético, os meios de produção pertenciam totalmente ou em grande parte ao Estado; e era o controle exercido coletivamente pelos gestores sobre $o$ aparelho de Estado que lhes garantia a propriedade desses meios de produção.

Nos países tradicionalmente incluídos na esfera de influência norte-americana verifica-se aquela mesma modalidade, à medida que existem empresas públicas $\mathrm{e}$ estatizadas, mas a sua importância é secundária. $\mathrm{O}$ sistema mais significativo de apropriação coletiva resultou aqui da fragmentação das formas burguesas de propriedade. $\mathrm{O}$ desenvolvimento das sociedades por ações teve como efeito, na esmagadora maioria dos casos, a dispersão dessas ações, de maneira que cada um dos acionistas não dispõe de nenhuma possibilidade de influenciar a orientação da empresa. Daí a grande mobilidade das ações. Em vez de constituírem um quadro familiar estável perpetuado pela herança, como sucede com a propriedade privada burguesa, as ações, adquiridas isoladamente ou em pequenos lotes, desde o início se destinam a ser transacionadas e têm, portanto, um elevado grau de liquidez. Acabam por equivaler a uma forma de depósitos a prazo.

$E$ a reduzida percentagem de acionistas com direito a participar nas Assembléias Gerais avalia a atuação das administrações mediante critérios exclusiva-

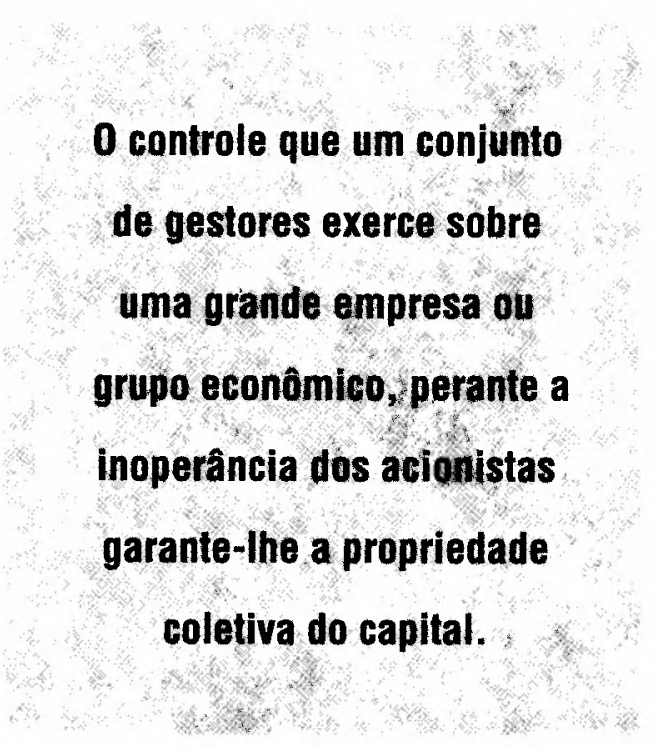

mente a curto prazo, interessando-se apenas por obter os maiores dividendos imediatos. Com esta perspectiva seria impossível dirigir uma grande empresa.

Fragmentada a antiga propriedade burguesa numa multiplicidade de parcelas ínfimas que não conferem aos detentores nenhum poder de decisão, este passou a caber inteiramente aos gestores das empresas. O capital não é uma soma de bens materiais ou títulos financeiros; é a supremacia que se exerce em dadas relações sociais e econômicas. O capital é a capacidade de enquadrar os trabalhadores no processo de produção de mais-valia, de orientar o seu decurso e de se apropriar dos seus resultados. $O$ controle que um conjunto de gestores exerce sobre uma grande empresa ou grupo econômico, perante a inoperância dos acionistas garante-lhe a propriedade coletiva do capital.

O mesmo sucede quando são as instituições de poupanças, incluindo os fundos de pensões com base sindical, a deter grandes lotes de ações. Em primeiro lugar, utilizam-se exatamente do mesmo 
modo que os particulares, para beneficiarem-se com as alterações de cotação e protegerem-se da inflação. Em segundo lugar, os administradores das instituições de poupança são eles próprios gestores, que controlam os fundos ao seu dispor sem ter a propriedade formal das instituições.

Mesmo quando os gestores de uma empresa recebem sob forma de ações uma parte da remuneração não se convertem por isso em proprietários burgueses. O objetivo é o de permitir que aproveitem as flutuações da bolsa e, portanto, o princípio orientador continua a ser o da mobilidade das ações, que não passam a constituir nenhum quadro estável e hereditário de apropriação. $\mathrm{O}$ mesmo raciocínio se aplica quando os gestores, por sua iniciativa, compram ações da empresa que administram. A vantagem, relativa a adquirir ações de outras empresas, consiste no fato de estarem especialmente bem informados acerca dos lugares onde exercem a atividade. Tem ainda sucedido que, para enfrentar ameaças de controle por um grupo rival, a administração adquira maciçamente ações da empresa que dirige. Procura assim unicamente impedir um eventual despedimento ou subalternização. Passado o perigo retoma-se o quadro anterior de propriedade. Para formar uma opinião sobre os resultados de todos estes mecanismos basta recordar que a percentagem das ações das 120 maiores sociedades norte-americanas detida pelos seus chief executives, que era de $0,3 \%$ em 1938 , desceu para $0,047 \%$ em 1974 e, em 1988 , reduzia-se a $0,037 \%{ }^{1}$.

Este sistema de propriedade tornou-se de tal modo dominante nas principais empresas que mesmo proprietários burgueses passaram a comportar-se consoante as normas que definem os gestores. O exemplo da Ford Motor Co. parece-me especialmente elucidativo. Quando Henry Ford II se afastou da direção, embora $40 \%$ das ações com direito de voto fossem ainda controladas pela família, os seus três membros ativos na empresa em nada se destacavam dos restantes gestores. Depois, ao aposentar-se, o vicepresidente William Clay Ford, neto do fundador, pela primeira vez os escalões de topo da administração deixaram de ter elementos da família, apesar de ela continuar a ser uma acionista influente ${ }^{2}$. O sistema gestorial prevalece hoje, ainda que se mantenham quadros de propriedade formalmente burgueses.

Uma profunda remodelação operada nas esferas do poder levou a que na última década, nos países tradicionalmente integrantes da área de influência norteamericana, se desmantelasse em boa parte o sistema de economia pública ou estatizada.

No decorrer do tempo, com o desenvolvimento da concentração do capital, foram-se estreitando as relações entre as maiores empresas, a tal ponto que puderam prescindir da mediação governamental e tomar elas próprias a iniciativa na organização global da sociedade. Puderam por isso também capturar para a sua órbita aparelhos administrativos que se haviam desenvolvido na esfera clássica do Estado. O sistema político tradicional foi assim atacado duplamente, circunscrito a partir do exterior e desagregado pelo interior, começando as grandes unidades econômicas a apresentarem-se como os principais órgãos do poder. Na sua expansão as sociedades multinacionais coroaram este processo porque, ultrapassando as fronteiras, abrem um campo de ação ao qual mal podem responder governos restritamente nacionais. E desta maneira o Estado centralizado, que tem nos ministérios e no parlamento o vértice obrigatório, dá progressivamente lugar a uma organização pluricentrada, constituída pela rede que une as maiores unidades econômicas e administrativas e em que cada uma delas forma um dos múltiplos pólos principais.

Deste modo, entrou em franco declínio o quadro de propriedade assente no aparelho central de Estado, que presidira à formação das empresas públicas e às estatizações. E desenvolveu-se a outra das formas de propriedade típicas da classe dos gestores, resultante da dispersão das ações, perfeitamente adequada à multiciplicidade de centros que passou a caracterizar a vida política.

$\mathrm{Na}$ grande parte dos países da esfera norte-americana, os governos têm vendido ou a totalidade de algumas empresas de que eram proprietários, ou participações majoritárias nas empresas ou participações minoritárias. Nos dois primeiros
2. THE ECONOMIST 3 OUt 1987, p. 75,4 mar. 1989, p. 71. 


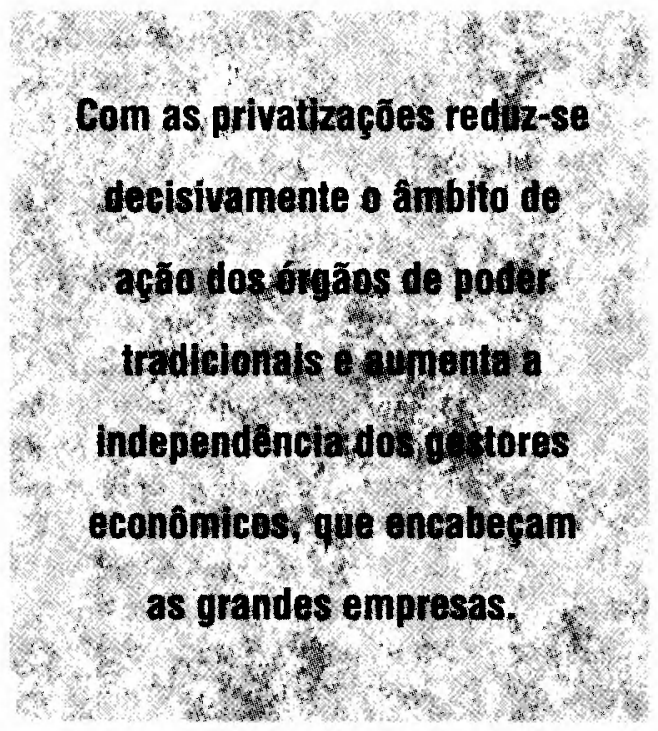

casos, os gestores inseridos no sistema centralizado de apropriação transitaram para o outro sistema. Este processo pode seguir formas diversas.

Uma das formas adotadas em países economicamente desenvolvidos da área norte-americana é a venda em bloco de empresas estatais, ou de participações nas empresas, a grandes grupos do setor privado.

Outra forma, corrente também nesses países mais desenvolvidos, consiste na dispersão das ações das empresas estatais entre um elevado número de pequenos compradores. Como os novos acionistas individuais, estão impossibilitados de exercer qualquer intervenção na orientação das empresas, elas continuam a ser controladas pelos seus gestores. $O$ Reino Unido constitui talvez o melhor exemplo, embora a deliberada confusão com que tantas vezes são apresentados os fatos obrigue a esmiuçar um pouco a análise.

Em 1963, 59\% das ações das sociedades britânicas com cotação oficial estava nas mãos de particulares, reduzindo-se a $37,5 \%$ em 1975 e, em 1984, a $23 \%$. O resto pertencia sobretudo a instituições de poupanças, como companhias de seguros e fundos de pensões, além de empresas estrangeiras. Os particulares preferiam canalizar as suas economias para aquelas instituições, de maneira que o número total de acionistas individuais diminuiu no período considerado. Eram 2,5 milhões em 1966, 2,1 em 1973 e 2,0 em 1980, número que se mantinha em 1983.
Porém, em vez de tomar como critério de avaliação a percentagem de ações detida por particulares, o governo Thatcher preferiu dar relevo ao número de proprietários de ações; ocultava-se assim um aspecto importante dos mecanismos de controle da economia, para se mostrar apenas o grau de dispersão desses títulos simbólicos. Em 1986, o governo anunciou que o número de acionistas subira para 6 milhões, o equivalente a $14 \%$ da população adulta. A euforia foi prematura e deveu-se a erros básicos no método de inquérito seguido. Até a privatização da British Telecom, em 1984, só entre $4 \%$ e $5 \%$ da população adulta possuía ações: com essa privatização o número subiu para $8 \%$ e seria de $9 \%$ em março de 1986 , embora outros inquéritos anunciassem que, no final da primeira metade desse ano, a proporção era de $8,3 \%$ ou $8,5 \%$ mas em fevereiro de 1987 os acionistas já eram 8,5 milhões, correspondentes a $20 \%$ da população adulta, e 9 milhões no terceiro trimestre desse ano. A situação no Reino Unido começava assim a aproximar-se dos Estados Unidos, onde 27\% dos adultos em 1987 eram proprietários de ações.

Mas, apesar desse acréscimo dos acionistas particulares, o valor das ações possuídas por instituições aumentou mais depressa do que o valor das detidas individualmente, o que se explica pelo fato de os particulares, ao adquirir ações, procurarem apenas um refúgio para as suas poupanças, sem quaisquer ilusões quanto a uma participação significativa no capitalismo. As variações etárias são, aliás, sugestivas do objetivo pretendido no Reino Unido com a compra de ações. $\mathrm{Na}$ fai$x a \operatorname{dos} 25$ aos 34 anos, correspondente aos elementos mais ativos e em hipotética ascensão social, só $6 \%$ adquirira ações, o que revela uma proporção inferior à média; na faixa entre os 55 e 64 anos, com a aproximação da aposentadoria, o número subira a $13 \%$, manifestando o desejo de obter uma garantia econômica para a velhice; acima dos 65 anos a percentagem diminuia, suprindo-se então parcialmente com a venda de ações a insuficiência das pensões ${ }^{3}$.

Quaisquer que sejam as formas de privatização adotadas, o que muda? Antes os gestores econômicos sofriam pressões
3. Para a análise da situação no Reino Unido ver The Economist 23 jul. 1983, p. $76 ; 22$ fev. 1986 , p. $55-58 ; 26$ abr. 1986 , p. $67 ; 3$ mai. 1986 , p. $97-98 ; 10$ mai. 1986, p. $85 ; 14$ jun. 1986 , p. $75 ; 12$ set. 1987 , p. $83-84,3$ out. 1987, p. 20 
por parte dos gestores políticos inseridos no aparelho central de Estado. Com as privatizações reduz-se decisivamente o âmbito de ação dos órgãos de poder tradicionais e aumenta a independência dos gestores econômicos, que encabeçam as grandes empresas. "O melhor motivo para

\section{Tem sido proposta a distribuição}

\section{de ações de cada empresa aos}

$$
\text { seus trabalhadores, consoante }
$$

um sistema que classifiquei

como capitalismo dos sindicatos

porque, na realidade,

são os dirigentes sindicais

a assumir 0 controle.

privatizar - consoante Alain Juppé, um político (francês) conservador neogaullista e ex-ministro do orçamento - é o de impedir que o governo tenha o poder de nomear e demitir os diretores das empresas estatais" 4 .

Nos países menos desenvolvidos da esfera de influência norte-americana, onde não existe um mercado particular de ações com dimensão suficiente, a privatização tem-se realizado mediante a venda de empresas públicas, quer a capitalistas estrangeiros, quer a sociedades multinacionais, quer - quando existam - a grupos econômicos com sede no país. Nestes casos é o quadro de propriedade vigente na entidade compradora que preside diretamente às empresas privatizadas.

O desmantelamento das economias de tipo marxista não revela nenhum declínio das formas gestoriais de propriedade, nem uma ressurreição da burguesia clássica nas esferas superiores de decisão econômica.

Nos regimes soviéticos vinham de há muito a exercer-se as mesmas pressões que levaram, na área de predomínio dos 4. Idem, ibidem, 8 abr. 1989, $p$. 84.

5. Idem, ibidem, 25 jan. 1992, p. 80. de poder. Este processo foi um dos responsáveis pelas sucessivas reformas de Khruchtchev e de Kossyguin, pelo lançamento da perestroika e, afinal, pela completa derrocada do aparelho central. No Ocidente, a transição pôde operar-se gradualmente porque coexistiam duas formas de propriedade gestorial; a decorrente da centralização governamental foi progressivamente ultrapassada pela resultante da dispersão das ações, adequada ao sistema pluricentrado que se fundamenta nas principais unidades econômicas. Mas na antiga esfera soviética a classe dos gestores assegurava a sua propriedade exclusivamente pelo controle mantido sobre os órgãos centrais do Estado, sem possuir oficialmente qualquer outra forma de propriedade adaptada às tendências recentes. São essas novas formas que estão hoje a ser criadas, com enormes perturbações que explicam tanto a demora nas medidas a adotar como o fato de as empresas estatais continuarem a prevalecer.

Uma das principais dificuldades que atrasam o desmembramento da economia estatal deve-se à não existência de um mercado de ações, sendo portanto impossível estabelecer antecipadamente uma cotação para a sua venda.

Além disso, se em alguns países da antiga esfera soviética, como a Polônia e a Hungria, uma longa série de reformas tinha permitido a emergência de um setor empresarial privado relativamente ativo, não se podia contar nos restantes com a existência, pelo menos em termos legais, de capitalistas particulares ou de grupos econômicos capazes de adquirir participações significativas nas empresas que os governos pretendem vender.

$O$ recurso ao capital estrangeiro não pode constituir a solução exclusiva, nem sequer a predominante, pois então o caráter nacional, que já não vigora na realidade econômica, desapareceria até como mito político, tornando mais precária a posição dos governantes perante a população.

Na China, empresas estatais começaram desde finais de 1991 a emitir ações reservadas a investidores estrangeiros, mas no início de 1992 previa-se que, no decurso desse ano, apenas duas dezenas de companhias seguissem o sistema ${ }^{5}$. O 
interesse dessa operação é meramente secundário, mais importante sob o ponto de vista da atração de capitais externos do que da transformação das formas de propriedade.

O único caso em que pôde proceder-se a uma completa desnacionalização foi na antiga República Democrática Alemã, porque o país deixou de existir. Esvaziou-se da força de trabalho e, portanto, do capital! As privatizações tomam aí fundamentalmente a forma de uma aquisição por grupos econômicos centrados na Alemanha Ocidental, a preços aliás incrivelmente baixos e incluindo múltiplos subsídios, tanto explícitos como camuflados. De julho de 1990 até ao final de julho de 1991, período em que se venderam as firmas industriais mais promissoras, só para menos de $4 \%$ vieram os compradores de fora das atuais fronteiras; e também esmagadora maioria das pequenas empresas de serviços foi vendida a alemães ${ }^{6}$. Relativo ao total das privatizações realizadas desde $o$ início do processo até ao final de novembro de 1991 , só $2,1 \%$ disseram respeito a compradores estrangeiros ${ }^{7}$.

Para ultrapassar a ausência de mercados nacionais de ações, alguns economistas e políticos têm proposto a distribuição de ações de cada empresa aos seus trabalhadores, consoante um sistema que classifiquei como capitalismo dos sindicatos porque, na realidade, são os dirigentes sindicais a assumir o controle ${ }^{8}$. É essa a reivindicação de alguns setores da burocracia sindical russa, apoiados por uma faç̧ão importante do parlamento e, a partir de dezembro de 1992 , do próprio governo ${ }^{9}$; mas, na data em que escrevo, só haviam conseguido parcialmente os seus objetivos, como daqui a pouco veremos. E, em outubro de 1992, por ocasião de uma vaga de greves, a primeira-ministra polaca propôs um conjunto de medidas destinadas a conciliar os sindicatos, entre as quais se incluía a promessa de reservar para os trabalhadores $10 \%$ das ações das empresas a privatizar ${ }^{10}$. Mais significativo é o fato de, em meados de 1992, acima de 3000 empresas chinesas terem repartido ações entre o pessoal ${ }^{11}$.

Porém, esta opção defronta-se freqüentemente com a hostilidade de grande parte dos empresários, pois reforçaria as po- sições negociais da burocracia sindical, precisamente no momento em que se procura impor nesses países uma rigorosa contenção dos custos laborais e uma queda drástica do nível de vida.

Assim, tomou corpo outra proposta, que prevê a distribuição de ações pela população em geral. Na verdade existe já - pelo menos - um precedente canadense, de há cerca de uma década e meia.

Em três anos de exercício um governo socialista na British Columbia, a terceira maior província do Canadá, nacionalizara várias empresas muito importantes no setor de recursos naturais. Em 1975, foi eleito primeiro-ministro da província William R. Bennet, opositor da propriedade estatal, que pôs em prática um plano de privatização mediante o qual se ofereceram a cada um dos 2,4 milhões de residentes canadenses da província cinco ações da companhia holding governamental, a British Columbia Resources Investment Corp., correspondendo estes cerca de 12 milhões de ações a $80 \%$ do total ${ }^{12}$.

No final de 1988 e princípios do ano seguinte um grupo de três economistas chineses propôs a emissão de senhas que seriam dadas às autarquias locais, às universidades e eventualmente a trabalhadores individuais. As senhas usar-se-iam na aquisição de companhias estatais, servindo para comprar ações em oferta pública. Começaria deste modo a constituirse um mercado de ações ${ }^{13}$. Este tipo de sugestões criou raízes e na província de Guangdong, onde as reformas econômicas têm sido levadas mais longe, falou-se na possivel reunião das empresas estatais em companhias holding cujas ações seriam vendidas ou dadas, numa primeira fase aos assalariados das empresas e, posteriormente, à população em geral ${ }^{14}$. Em agosto de 1992, no entanto, as autoridades experimentaram outro sistema, vendendo ao público senhas, até um máximo de dez unidades por comprador, entre as quais se sorteará posteriormente aquelas que darão direito a participar no leilão de ações de um certo número de empresas, ainda a determinar. Estava previsto que seria premiado apenas $1 / 10$ das senhas emitidas, ou talvez mesmo só $1 / 5$, mas apesar disso a concorrência de interessados foi tão grande que resultaram vários feridos ${ }^{15}$.
6. Idem, ibidem, 14 set. 1991 , p. 22.

7. Idem, ibidem, 21 mar. 1992 p. 77 .

8. BERNARDO, João. Capital Sindicatos, Gestores. São Paulo: Vértice, 1987, p. 11-16.

9. THE ECONOMIST, $15 \mathrm{fev}$. 1992, p. 72; 29 ago. 1992, p. 20; 23 jan. 1993, p. 36.

10. Idem, ibidem, 24 out. 1992 , p. 36.

11. Idem, ibidem, 20 jun. 1992 , p. 74 .

12. FORTUNE, 26 fev. 1979 , p. 18-20 e The Economist, 22 fev. 1986, p. 58.

13. THE ECONOMIST, 14 jan. 1989, p. 62; idem 11 fev. 1989, p. 19.

14. Idem, ibidem, 30 nov. 1991 , p. 61.

15. Idem, ibidem, 15 ago. 1992, p. 46. 
O sistema de senhas encontrou um amplo eco na antiga União Soviética, onde foi muito debatido, e, na Europa de Leste, pelo menos na antiga Tchecoslováquia, na Polônia e na Hungria.

No que até há pouco foi a Tchecoslováquia, o governo elaborara inicialmente um sistema mediante o qual as empresas a privatizar que não conseguissem encontrar um comprador nem um parceiro estrangeiro deveriam vender, a troco de senhas, a totalidade das suas ações.

Posteriormente, os administradores de empresa e a burocracia ministerial e partidária que os apóia conseguiram introduzir uma importante modificação no projeto, fazendo com que só uma parte de cada empresa fosse posta em venda pública. Nas mais de 1200 firmas que deveriam ser incluídas nas operações de privatização entre maio de 1992 e o outono do mesmo ano, apenas uma participação média de $50 \%$ seria oferecida ao público. Deste modo os gestores em exercício prepararam-se para entrar no novo sistema com uma posição consideravelmente reforçada.

E um desenvolvimento de outro tipo veio consolidar ainda a situação da classe gestorial. Pelo método de privatização adotado na Tchecoslováquia as ações foram cedidas em troca de senhas. O Estado vendeu essas senhas por uma soma equivalente ao salário semanal médio e elas foram utilizadas para adquirir ações em leilão público. Conforme o interesse manifestado pelos compradores relativo a cada empresa, assim se fixou o preço das ações em termos de senhas. Esperava-se ainda a promulgação de outra lei, que fixasse as condições em que as ações, depois de terem sido adquiridas mediante senhas, pudessem ser transacionadas. Apesar disso, as previsões iniciais quanto ao número de interessados depressa se revelaram ultrapassadas, pois no início de 1992 foi tão grande a procura que tiveram de se emitir senhas temporárias. Em maio desse ano, 3/4 dos cidadãos adultos haviam adquirido senhas. Assim, antes ainda de se ter começado a efetuar a privatização já se fizeram sentir todos os efeitos da fragmentação e dispersão dos títulos de propriedade, antecipando-se quanto às senhas a mesma situação que inevitavelmente ocorreu quanto às ações.
Surgiram várias centenas de Fundos de Investimento, a maior parte privados, mas alguns detidos por bancos estatais, oferecendo-se para pagar dentro de algum tempo pelas senhas que thes sejam confiadas um preço bastante superior ao seu valor nominal, mas evidentemente inferior ao da cotação que se presume que as ações venham nesse prazo a atingir. A expansão desses Fundos foi tão rápida que o governo promulgou em abril de 1992 uma lei proibindo-os de deter mais de $20 \%$ das ações em cada companhia. No mês seguinte, pouco antes da data oficialmente marcada para o início da oferta pública de ações, os Fundos de Investimento representavam $2 / 3$ das senhas emitidas e em meados do ano, com o processo já em curso, a proporção subira para $3 / 4$.

Esse processo de privatização colocou face a face os gestores das empresas e os gestores dos Fundos de Investimento, ficando o público de antemão afastado de qualquer participação decisiva. Por isso, antes ainda do começo das operações de venda, os administradores das empresas já tinham encetado informalmente conversações com os administradores dos Fundos, que vieram depois a dominar inteiramente os leilões de ações. Trata-se de uma reorganização interna da classe gestorial, que de modo nenhum põe em causa a sua hegemonia ${ }^{16}$.

Em meados de 1992, o governo tchecoslovaco tinha leiloado ações em quase 1500 empresas e previa-se então que outras 1200 começariam a ser privatizadas no início de 1993. As eleições de junho deram a vitória na parte tcheca aos defensores deste sistema de privatização: entre os Eslovacos, apesar de se contarem 2.5 milhões de pessoas suficientemente interessadas para terem adquirido senhas, triunfaram as forças políticas partidárias de um ritmo de reformas muito mais lento, caminhando-se a partir dessa altura para o fracionamento do país em duas entidades, que assumiram a independência no início de 1993. As complicações institucionais e jurídicas desse processo, se não interromperam as privatizações, foram, no entanto, suficientes para retardá-las ${ }^{17}$. Na Eslováquia, durante a fase de transição anterior à independência, o governo freou a privatização de 
algumas empresas importantes, anunciou a intenção de manter para o Estado uma posição dominante em áreas econômicas estratégicas e lançou dúvidas sobre a continuidade do sistema de senhas ${ }^{18}$. Nessa ocasião um dos principais economistas do partido governamental sugeriu a emissão de golden shares reservadas ao Estado, que se asseguraria assim de um direito de decisão prioritário relativo aos restantes acionistas ${ }^{19}$. O novo Estado começou a vida independente com o programa de privatizações suspenso e os ministros divididos quanto à forma de o continuar ${ }^{20}$.

\section{Ao cidadão político pretênde} substituir-se o cidad5o

acionista, q. que se adequa às transformaçōes operadas nos sistemas do poder, quando $o$ aparelno politico tradicional declina perante as grandes empresas.

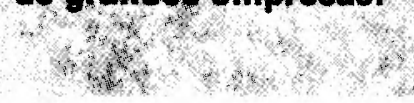

Inicialmente o plano polaco previra que no decurso de 1992 todos os cidadãos adultos recebessem senhas a serem depositadas em Fundos de Privatização. Deveriam criar-se entre cinco e vinte Fundos, administrados na prática por gestores estrangeiros, que usariam as senhas para adquirir ações em grandes empresas estatais. Os Fundos não se limitariam depois a vender e comprar ações, mas também participariam ativamente na gestão, podendo reestruturar as empresas, organizar joint ventures com investidores estrangeiros e expandir as sociedades ou declarar a sua falência. Além disso, ou os Fundos, ou um futuro Fundo Nacional de Pensões, deveriam ainda administrar muitas das participações que o Estado manteria nas empresas. Após um certo período os detentores individuais de senhas seriam autorizados a transacio- nar as ações que lhes cabiam nos Fundos.

$E$ em qualquer altura os particulares, incluindo cidadãos de outros países, poderiam livremente comprar ações por dinheiro. Discutia-se ainda qual havia de ser o último destino dos Fundos ${ }^{21}$.

O governo de Tadeusz Mazowiecki previra a privatização de metade do setor estatal até 1993, devendo estar completo o processo dois anos mais tarde. Porém, cada um dos sucessivos governos, não só tem atrasado a entrada em vigor do plano, como reduzido o seu âmbito, limitando-o a empresas responsáveis por apenas $7 \%$ do output industrial. Até que, afinal, parece ter-se desistido da privatização maciça, recorrendo-se a uma solução gradual, que não passou ainda das etapas iniciais ${ }^{22}$.

Enquanto a República Federada da Rússia formava parte da extinta União Soviética, adotara-se legislação prevendo para 1992 a distribuição de senhas aos cidadãos, que com elas poderiam adquirir ações ${ }^{23}$.

Mas o plano de privatizações anunciado pelo governo russo em fevereiro de 1992, e reelaborado numa versão ampliada cinco meses mais tarde, pretende conjugar a distribuição de ações ao pessoal das empresas e a sua venda pública; e, neste último tipo de operações, procura combinar as vendas por senhas e as vendas a dinheiro. As empresas podem optar por uma de duas formas de privatização.

Mediante uma delas, que será empregada em cerca de metade dos casos, os trabalhadores receberão gratuitamente, ou $25 \%$ das ações da empresa onde exercem a atividade, ou o equivalente a 20 salários mínimos mensais, consoante o que resultar num valor inferior. No projeto adotado, essas ações não conferirão direito de voto nas assembléias de acionistas, apesar de o governo estar a sofrer pressões para transformá-las em ações com plenos direitos. Os trabalhadores se beneficiarão também de um desconto de $30 \%$ sobre o valor nominal de mais $10 \%$ das ações, se conseguirem arrematá-las em leilão, contra senhas ou dinheiro. Os membros da administração da empresa terão, por seu lado, direito de opção relativo a $5 \%$ das ações, com capacidade de voto. Outros $10 \%$ das ações serão leiloa-
18. Idem 28 nov. 1992 , p. 47.

19. RESPEKT transcrito em Courrier International, 25 jun. 1992, p. 12.

20. THE ECONOMIST, 16 jan. 1993, p. 31-32.

21. Idem, ibidem, 11 maio 1992, p.65-66; 21 set. 1992. A Survey of Business, p. 16-17; 21 mar. 1992, p. 6; 23 jan. 1993, p. 25.

22. Idem, ibidem, 22 fev. 1992, p. $18 ; 16$ maio 1992 , p. $14 ; 13$ jun. 1992, p. 32.

23. Idem, ibidem, 6 jul. 1991, p. 70. 
24. Idem, ibidem, 21 dez. 1992 p. $110 ; 4$ jan. 1992 , p. $22 ; 15$ fev. 1992, p. 20, 71-72; 11 abr. 1992, p. 86; 25 abr. de 1992, p. 20; 20 jun. 1992 , p. 15; 18 ju. 1992 , p. $64 ; 10$ out. 1992 , p. $30 ; 7$ nov. 1992 , p. $40 ; 28$ nov. 1992, p. 77-78; 5 dez. 1992. A Survey of Russia, pp. 5, 28; 16 jan. 1993, p. 66-67.

25. Idem, ibidem, 11 maio 1991 , p. 66

26. Idem, ibidem, 14 abril 1990 , p. $15 ; 11$ maio 1991 , p. $65-70$ 21 set. 1991. A Survey of Business, p. 16; 19 dez. 1991, p. 28. dos entre o público em geral, admitindose o emprego de senhas. Finalmente, os restantes $50 \%$ serão vendidos num bloco único, cujo adquiridor beneficiará, por conseguinte, do direito de controle. Essa metade das ações tanto poderá ser comprada por um só investidor, como por um dos múltiplos Fundos de Investimento que entretanto proliferaram, sob o controle de bancos, e que conseguiram reunir grande parte das senhas distribuídas ao público. Menos de um mês depois de o governo ter estabelecido a regulamentação legal dos Fundos, mais de 300 tinham sido registrados. Como as senhas são denominadas em rublos e podem ser vendidas por dinheiro, numa situação de agravamento das condições econômicas, boa parte da população sofre pressões para vender as senhas antes de poder participar em qualquer leilão de ações, tornando-se por conseguinte mais fácil aos Fundos de Investimento, e mesmo a especuladores individuais, reunir quantidades colossais de senhas.

$\mathrm{Na}$ outra metade dos casos, em que pelo menos $2 / 3$ do pessoal de uma empresa votou a favor da aquisição da maior parte das ações, recorrer-se-á a uma forma diferente de privatização. Os trabalhadores e a administração poderão, em conjunto, comprar $51 \%$ das ações, por um preço equivalente a 1,7 vezes o valor contábil da firma conforme o estabelecido em janeiro de 1992, e sendo possível pagar em senhas metade desse montante. Das ações restantes, $10 \%$ serão vendidas publicamente contra senhas e $39 \%$ por dinheiro.

Nos primeiros dias de abril de 1992 iniciaram-se leilões públicos referentes a estabelecimentos municipais, de escassa importância econômica e exteriormente ao sistema de senhas. Mediante esse sistema os projetos governamentais prevêem a privatização, até o final de 1993, de mais de 6000 médias e grandes empresas e 100.000 pequenas empresas e estabelecimentos comerciais: e, até o final de 1994, de mais 4000 grandes empresas ${ }^{24}$.

Ainda na área da extinta União, o governo da Lituânia tencionara dar a todos os cidadãos, em 1991, senhas para adquirir ações nas empresas estatais. As senhas não poderiam ser transacionadas e só seria possível comprar ações por dinheiro num montante equivalente ao valor nominal das senhas que se possuíssem. $O$ objetivo destas restrições era o de impedir que os membros do antigo regime soviético, com maior fortuna acumulada, se convertessem em poderosos acionistas ${ }^{25}$.

$\mathrm{Na}$ Hungria, o Fórum Democrático defendeu que se concedesse a comunidades locais, fundações de caráter social, hospitais, universidades e aos assalariados das empresas estatais o direito de adquirir ações a preços mais baixos. Mas o governo rejeitou a proposta, convicto de que a privatização encontraria uma base suficiente entre os gestores dessas empresas, os empresários privados já surgidos ao abrigo das reformas anteriores e os capitalistas estrangeiros. Só os Democratas livres, na oposição, continuaram a propor a distribuição de ações pela população até que, no final de 1992, com o declínio dos investimentos externos, o governo parece ter começado a interessar-se pela possibilidade de aplicar um sistema de senhas ${ }^{26}$.

Soluções deste tipo agradam a alguns dos novos ideólogos das classes dominantes. Estando já inteiramente desacreditado o mito soviético de que a propriedade estatal pertenceria a todos, porque o Estado seria de todo o povo, dá-se curso a um novo mito, de que a propriedade das empresas a todos caberá porque todos hão de ter ações. Ao cidadão político pretende substituir-se o cidadão acionista, o que se adequa às transformações operadas nos sistemas de poder, quando o aparelho político tradicional declina perante as grandes empresas.

Mas, como o capitalismo ocidental demonstrou, ações individuais ou em pequenos lotes não convertem os seus possuidores em proprietários do capital. Pelo contrário, asseguram que os administradores das empresas exercendo sobre os processos econômicos um controle que os acionistas não podem pôr em causa, sejam em conjunto os verdadeiros proprietários do capital. A dispersão das ações garante aos gestores a continuidade da sua hegemonia.

Enquanto os projetos se elaboram e são emanados e voltam a ser propostos e se deparam com obstáculos imprevistos são substituídos por novos projetos, vão tomando corpo outras realidades. 
Na Polônia, em 1989, durante os últimos estertores do regime marxista, os administradores de várias empresas estatais começaram eles próprios a adquiri-las, no quadro das privatizações. A operação podia ser simples, através da compra em condições muito favoráveis. Ou podia ser mais complexa, como sucedia quando, numa primeira fase, se criavam sociedades privadas, com instalações e capital mínimos, nas quais administradores detinham ações de empresas estatais: numa segunda fase, essas empresas estatais recusavam encomendas, que passavam para as referidas sociedades privadas: para isso as empresas privadas alugavam às estatais instalações, material e força de trabalho em condições favoráveis. Os lucros eram partilhados com aqueles que, enquanto gestores das empresas estatais, as pilhavam em benefício das sociedades de que eram acionistas ${ }^{27}$.

Afinal, perante a inoperância econômica do governo central, esse quadro tem continuado até hoje a presidir na prática às privatizações. Os gestores de um grande número de empresas do Estado, ou as integram em joint ventures com a aprovação das autoridades locais, mais facilmente manobráveis: ou têm simplesmente adquirido as empresas; ou apressam a sua falência e precipitam-na mesmo por métodos fraudulentos, sendo depois as instalações e a maquinaria compradas ao desbarato por sociedades particulares; ou vão paulatinamente vendendo a empresas particulares o patrimônio das empresas estatais que tão bem administram. Até o final de 1992 mais de 1500 compa nhias, num total de 8000 , haviam sido privatizadas por estas formas, ou estavam a sê-lo, consolidando-se assim a fusão entre os capitalistas até agora decorrentes do aparelho central do Estado e os capitalistas particulares ${ }^{28}$. E a privatização de empresas mediante processos de falência tem para os novos proprietários a vantagem suplementar de poderem reduzir drasticamente a força de trabalho e não estarem obrigados pelos compromissos tomados para com a anterior pessoal.

Do mesmo modo na Hungria, também em 1989, promulgou-se uma lei que permitiu aos principais gestores das maiores empresas desencadear operações de privatização em que, coligados com capita-
Muitos gestores, para

manterem uma posição

privilegiada, podem ter de se

tornar temporariamente

proprietários privados 8

individuais do capital.

E assumem então a forma

aparente de burgueses para,

na prática, continuarem

como gestores.

listas particulares nacionais ou estrangeiros, puderam adquirir nessas empresas participações muito consideráveis, ou até majoritárias. $\mathrm{O}$ processo foi o seguinte: $20 \%$ das ações deviam, por lei, ser entregues a um fundo estatal e os capitalistas particulares deviam avançar com um mínimo de outros $20 \%$ : se adiantassem mais, porém, conquistavam evidentemente o controle e tinham então a liberdade de vender o restante aos seus aliados na administração da empresa, em termos especialmente favoráveis ${ }^{29}$.

Outra forma de privatização consistiu na divisão de empresas estatais em múltiplas subsidiárias, constituídas como sociedades que venderam ações reciprocamente e a terceiros, deixando à empresa originária um mínimo de instalações, além das dívidas ${ }^{30}$.

De uma maneira ou outra, este tipo de situações parece ser geral em todos os países da antiga esfera soviética ${ }^{31}$.

Mesmo aqueles gestores mais diretamente comprometidos com os regimes marxistas mantiveram, após a derrocada final, amplas possibilidades de atuação. $E$ tanto mais se reforçarão quanto mais rapidamente forem levadas a cabo as privatizações pois, em boa parte dos casos, são eles os únicos com disponibilidades financeiras e contatos econômicos suficientes para de imediato poderem participar ativamente no processo. $O$ mesmo se pas-
27. Idem, ibidem, 26 ago. 1989, p. $20 ; 14$ abr. 1990 , p. 17.

28. Idem, ibidem, 19 dez. 1992, p. $28 ; 23$ jan. 1993, p. 75.

29. Idem, ibidem, 26 ago. 1989 , p. $20-21 ; 14$ abr. 1990, p. $15-$ 16.

30. Idem, ibidem, 14 abr. 1990 , p. 16.

31. Idem, ibidem, 18 abr. 1992 , p. 24. 
32. MBEMBE, Achile. Le Véritable Enjeu des Débats sur la Démocratie. Afrique des Comptoirs, ou Afrique du Dévelopement. Le Monde Diplomatique, jan. 1992, p. 24.

33. THE ECONOMIST, $14 \mathrm{abr}$. 1990, p. 17.

34. Idem, ibidem, 23 jan. 1993, p. 25.

35. Cito algumas estimativas da elevada dimensão atingida pela economia oculta em Crise da Economia Soviética. Coimbra: Fora do Texto, 1990, p. 15.

36. THE ECONOMIST, 16 jan. 1993, p. 67.

37. Idem, ibidem, 15 fev. 1992 , p. 20.

38. Idem, ibidem, p. 72.

39. Idem, ibidem, 18 jul. 1992, p. 64 .

40. Idem, ibidem, p. 78-79 sa na África, onde a precipitação em privatizar tem permitido o reforço social e político daquelas mesmas forças que sustentaram os antigos regimes e que são, agora, as únicas com capacidade para adquirir as empresas à venda ${ }^{32}$. Nem parece que essa situação preocupe os outros elementos das classes dominantes. Leio num prestigiado órgão do capital transnacional, especialmente interessado pelo que se passa a Leste: “... sem os estrangeiros e a tão desprezada nomenklatura será difícil encontrar pessoas desejosas de investir dinheiro a sério nas sete mil empresas estatais polacas ${ }^{\prime 33}$

Vai-se mais longe ainda na vespasiana indiferença aos odores do dinheiro, quando se entoam louvores à participação maciça que os capitais ilegais têm tido no processo de privatizações. Escreve o mesmo respeitável semanário a propósito de uma das mais importantes repúblicas saídas da antiga União Soviética: "Não é perseguindo os semi-criminosos que constituem a base da classe capitalista ucraniana que se pode favorecer as reformas. Pelo contrário, e ainda que seja difícil para os políticos aceitar o fato, deve manter-se um ambiente empresarial aberto" ${ }^{34}$. Nos últimos decênios o regime soviético só pudera funcionar porque em paralelo com o sistema legal, assente na planificação central, operava um sistema oculto, decorrente da autonomia cada vez maior assumida pelas grandes empresas e por centros de acumulação periféricos. De certo modo, a perestroika e a desagregação final do regime resultaram do fato de a economia oculta ter passado a dispor de uma capacidade de iniciativa superior à do centro oficial. Nestes termos, as avultadíssimas somas movidas ilegalmente ${ }^{35}$ não resultam apenas do banditismo e crime organizado e do tráfico de divisas. $\mathrm{O}$ importante é considerar que se operou uma verdadeira fusão entre todos os tipos de capital que circulam nesse quadro paralelo. O branqueamento de somas ilícitas, parece que reforçadas nos últimos tempos por outras provenientes de redes criminais estrangeiras, mistura-se com aqueles capitais extra-oficiais sem os quais o funcionamento regular da própria economia legal teria sido impossível. Esta "nova classe de investidores ativos, capazes em alguns casos de gastar uma quantidade de dinheiro surpreenden- te $e^{\prime 36}$, o que em nada nos deve surpreender, precipita-se hoje para a aquisição de grandes lotes de ações ou mesmo da totalidade de empresas.

Não só as privatizações rápidas, mas também os atrasos sofridos no processo e os obstáculos com que se têm deparado as medidas governamentais, servem aos gestores para restabelecer, na nova situação, as condições da sua hegemonia social.

$\mathrm{Na}$ Rússia, por exemplo, os mesmos administradores de empresas, que antes detinham o controle mediante a influência que exerciam sobre o aparelho de Estado central, controlam agora as unidades econômicas com um grau de autonomia tanto mais considerável quanto o governo da república se encontra em grande medida paralisado. Tornaram-se, exceto no nome, proprietários das empresas que administram ${ }^{37}$.

Esta situação explica que o governo, no grande plano de privatização anunciado em fevereiro de 1992, tenha conferido às burocracias locais um papel decisivo no desenrolar das operações ${ }^{38}$. É um indício do poder de fato detido por essas camadas da classe gestorial, de tal modo que na versão ampliada do programa divulgada alguns meses mais tarde prevê-se que representantes das agências locais de privatização tenham desde já assento na administração das mais importantes empresas a privatizar ${ }^{39}$.Ao mesmo tempo, dos 1500 bancos comerciais surgidos na Rússia, $4 / 5$ foram fundados por empresas estatais, que deles são proprietárias. E uma situação idêntica verifica-se na Ucrânia ${ }^{40}$.

Alguns destes casos são especialmente interessantes porque se caracterizam pelo recurso a uma fase transitória. Estando esgotadas as formas de propriedade mediadas pelo controle do aparelho político central, e quando se afigura difícil e demorada a generalização da forma de propriedade resultante da dispersão das ações, muitos gestores, para manterem uma posição privilegiada, podem ter de se tornar temporariamente proprietários privados e individuais do capital. E assumem então a forma aparente de burgueses para, na prática, continuarem como gestores.

Isto sucede apenas porque o quadro burguês de propriedade está hoje secundarizado e encontra-se inteiramente subordinado ao quadro gestorial. 